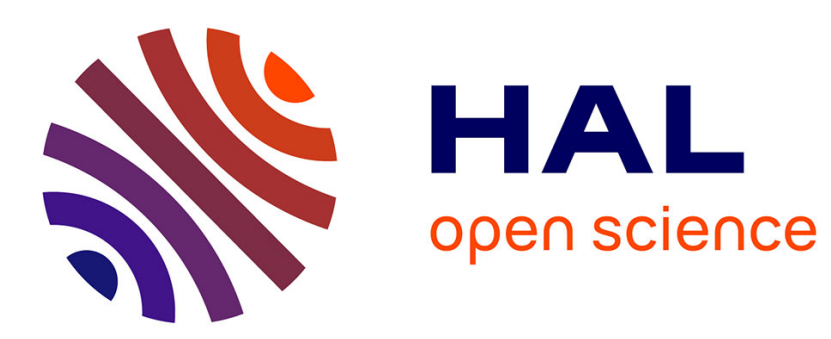

\title{
Global crisis and Financial destabilization in ASEAN countries. A microstructural perspective
}

Céline Gimet, Thomas Lagoarde-Segot

\section{To cite this version:}

Céline Gimet, Thomas Lagoarde-Segot. Global crisis and Financial destabilization in ASEAN countries. A microstructural perspective. 2011. halshs-00560218v2

\section{HAL Id: halshs-00560218 \\ https://shs.hal.science/halshs-00560218v2}

Submitted on 31 Jan 2011

HAL is a multi-disciplinary open access archive for the deposit and dissemination of scientific research documents, whether they are published or not. The documents may come from teaching and research institutions in France or abroad, or from public or private research centers.
L'archive ouverte pluridisciplinaire HAL, est destinée au dépôt et à la diffusion de documents scientifiques de niveau recherche, publiés ou non, émanant des établissements d'enseignement et de recherche français ou étrangers, des laboratoires publics ou privés. 
Global crisis and Financial destabilization in ASEAN countries. A microstructural perspective

Céline Gimet, Thomas Lagoarde-Segot

Janvier 2011 


\section{GATE Groupe d'Analyse et de Théorie Économique Lyon-St Étienne}

93, chemin des Mouilles 69130 Ecully - France

Tel. +33 (0)4 72866060

Fax $+33(0) 472866090$

6, rue Basse des Rives 42023 Saint-Etienne cedex 02 - France

Tel. +33 (0)4 77421960

Fax. $+33(0) 477421950$

Messagerie électronique / Email : gate@gate.cnrs.fr

Téléchargement / Download : http://www.gate.cnrs.fr - Publications / Working Papers 
Global crisis and financial destabilization in ASEAN countries. A microstructural perspective.

\author{
Céline Gimet ${ }^{\mathrm{a}}$, Thomas Lagoarde-Segot ${ }^{\mathrm{b}, *}$ \\ ${ }^{a}$ University of Lyon, Lyon, F-69003, France ; University of Lyon 2, Lyon, F-69007, France; \\ CNRS, GATE Lyon St Etienne, Ecully, F-69130, France \\ ${ }^{\mathrm{b}}$ Euromed Management, School of Management, Marseille \& DEFI, University of Aix- \\ Marseille, EA $n^{\circ} 4265$, France
}

\begin{abstract}
This paper investigates whether the ongoing financial crisis has destabilized the microstructures of ASEAN stock markets. Using daily stock market data from 2007 to 2010, we first develop a set of monthly country-level liquidity, efficiency, international integration and volatility indicators. We then analyze the impact of global market volatility shocks on those indicators, using a set of Bayesian S-VAR models. Finally, forecast error variance decomposition analysis and impulse response function permits to identify the magnitude and the symmetry of ASEAN financial systems' exposures to international shocks. Our results uncover significant and asymmetrical shock transmission channels. We draw implications for the design of future regional integration initiatives.
\end{abstract}

JEL classification: F32; F36; G15; C32

Keywords: Microstructures; Regional integration; Shock Vulnerability; SVAR

* Corresponding author. Tel: $+(0) 33491827$ 390; fax: $+(0) 33491827983$. E-mail addresses: gimet@gate.cnrs.fr (C.Gimet),thomas.lagoardesegot@euromed-management.com (T.Lagoarde-Segot). 


\section{Introduction}

The current global crisis highlights that financial openness creates new vulnerabilities and new sources of risk for emerging economies. According to the Committee of Global Financial Systems (2009), coping with financial globalization implies combining macroeconomic stability, exchange rate flexibility, sound capital account management, accumulation of foreign reserves and the development of resilient domestic financial systems. These policy recommendations may nonetheless sound like a déjà $v u$ in the ASEAN region ${ }^{1}$. These countries indeed underwent a "fast and furious" contagion episode during the late 1990's and subsequently implemented a set of reforms aimed at strengthening their financial sectors and minimizing the likelihood of speculative attacks (Corsetti et al., 1999, Chang and Velasco, 2000; Kaminsky et.al, 2003). For instance, banking sector supervision improved considerably - capital adequacy ratios now exceeding international norms - and nonperforming loans represent a small share of investment portfolios. Local banks also rely primarily on domestic funding sources: the ratio of loans to domestic deposits is inferior to one, implying stronger resilience to international liquidity shocks (Mohan and Kapur, 2010). In addition, exchange rate arrangements switched from pegged or fixed to floating regime during the past decade. As a result, nominal and real exchange rates smoothly appreciated between 2003 and July 2007 and depreciated in the 2007-2009 period, in line with net capital flows trends. Finally, regional policy cooperation improved. For instance, the Chang Mai Initiative ${ }^{2}$ reinforced regional financial surveillance and developed assistance mechanisms (such as bilateral swaps and repurchase agreement facilities) in the event of asymmetric liquidity shocks. In a similar

\footnotetext{
${ }^{1}$ The Association of Southeast Asian Nations (ASEAN) gathers Brunei Darussalam (1984), Cambodia (1999), Indonesia (1967), Laos (1997), Malaysia (1967), Myanmar (1997), Philippines (1967), Singapore (1967), Thailand (1967) and Vietnam (1995).

2 May 6, 2000, Chiang Mai, Thailand.
} 
fashion, the Asian Bond Market Initiative was launched in 2003 in order to develop regional liquid bond markets.

However, these policies failed to insulate the ASEAN economies from the global crisis. In the first quarter 2009 , economic growth rates were of $-6.2 \%,-9.6 \%,-7.1 \%, 0.4 \%$ for Malaysia, Singapore, Thailand and the Philippines, respectively ${ }^{3}$. 'Monsoonal' effects induced by the massive drop in external demand and the reversal of trade-related capital flows constitute the most obvious and most important factor. However, additional mechanisms may also be at play within the financial sector. In line the Keynesian 'animal spirits' hypothesis, one may argue that sudden shifts in domestic investors' expectations in reaction to adverse international economic information could affect the volume and the allocation of investment projects, resulting in additional aggregate economic losses. This process could impact ASEAN countries asymmetrically given the heterogeneous size and institutional arrangements of their capital markets. Analyzing these microeconomic - and psychological - channels would help disentangle the crisis transmission channels and raise useful information for policy makers seeking to deepen regional integration and enhance shock resilience.

Taking this into account, this paper investigates whether global volatility shocks induced structural breaks in equity market microstructures (including efficiency, volatility, international integration and liquidity). Our analysis suggests that the crisis modified asset pricing mechanisms by inducing changes in the behavior and anticipations of domestic investors, independently of legal arrangements regarding foreign investment. These results suggest the presence of psychology-induced market vulnerability, which should lead policy makers to rethink the role of government intervention. In addition, we highlight significant cross-country asymmetries. Larger markets like Singapore appear relatively more resilient to these destabilization channels, while smaller markets like Indonesia seem more significantly

\footnotetext{
3 The recession was nonetheless contained thanks to large economic stimulus programs. Annual 2009 GDP growth rates were of $-1.7 \%,-1.3 \%,-2.3 \%, 0.9 \%$ for Malaysia, Singapore, Thailand and the Philippines.
} 
affected. Divergent stock market institutions appear to be a source of asymmetric shock vulnerability in the ASEAN region.

Taking this into account, one useful regional integration initiative would be to homogenize financial regulations in the region, using the most resilient market - Singapore - as a benchmark. In this regard, a new Asia Stock Market Initiative (echoing recent developments in the bond markets), would be a welcomed policy development.

Policy efforts should thus be geared towards enhancing regional integration in this domain.

The remainder of the paper is structured as follows. Section 2 discusses the linkages between microstructure destabilization and economic volatility in the real sector. Section 3 presents the methodology. Section 4 discusses the results and section 5 brings together our conclusions.

\section{Microstructure destabilization and real sector losses}

Broadly defined, market microstructures refer to the process and outcomes of exchanging financial assets under a specific set of rules. Microstructure theory focuses on the economics of capital markets, including the role of information in the price discovery process, the measurement of transaction costs and the dynamics of market volatility. The quality of market microstructures modifies the outcomes of financial development in emerging markets (Lagoarde-Segot, 2009). Microstructure destabilization can also undermine the real sector.

\subsection{Informational efficiency}

Informational efficiency implies that the pricing of securities reflects all available information that is relevant to their valuation and that the allocation of savings corresponds to firm performance. Adverse shifts in efficiency levels have several economic consequences. First, it implies that financial resources are misallocated, resulting in macroeconomic losses. Second, insufficiently diversified investors always bear excessive risk. The related losses induce lower 
average consumption and higher consumption volatility. Third, lower efficiency increases noise trading, encourages herding behaviours; and therefore pushes up risk premia and the cost of capital for domestic firms, which results in a lower investment. Fourth, departure from efficiency undermines the market's capacity to raise capital given that managers cannot fully and credibly reveal information to outside investors and lenders. Fifth, tying managers' income to inefficient market prices creates wrong managerial incentives, and introduces strong disturbances in corporate governance mechanisms.

\subsection{Market volatility}

Sudden breaks in market volatility are usually viewed as a significant downside to equity market development. Excessive volatility increases the costs related to understanding and monitoring the basic features of the market. This limits market participation and financial development (Allen and Gale, 1994). Volatility also leads to a higher cost of capital through a higher risk-premium. This affects the NPV of investment and deters firms from stock market listing and capital expansion (Schill, 2004). Third, volatility can induce a misallocation of investments given that managers tend to get overly pessimistic in bear markets and overly optimistic in bull markets. For instance, Chirinko and Schaller (2001) showed that stock market overvaluation in Japan increased business fixed investment by at least 6-9\% during the bubble years 1987-89.

\subsection{Transaction costs}

Liquidity refers to the ability to buy and sell goods without incurring substantial costs to trade. Increases in trading costs may discourage investors and restrains the potential of emerging stock markets to mobilize resources for investment. Theoretical models and empirical research also suggest that liquidity risk is included in valuation models and thereby 
impacts the cost of equity. Third, liquidity impacts the market's ability to absorb informational shocks without destabilizing prices. A sudden drop in market liquidity therefore pushes up the ratio of the variance of prices to the variance of the shock, implying an increase in market volatility, with adverse economic consequences. Increased costs of trading undermine the ability of market participants to incorporate relevant information flows into their trading orders, and ultimately affect efficiency levels. Fifth, direct costs of trading such as brokerage fees constitute a diversion of resources that could otherwise be allocated to the productive sector. For instance, Carhart (1997) highlighted that the sum of actively managed funds exceeded $\$ 10$ billion per year in the US.

\subsection{Market integration}

Market integration implies that domestic assets are priced according to their exposure to international systematic risk, as the International Capital Asset Pricing Model becomes the relevant valuation model. This dynamic has been showed to diminish the cost of capital in emerging markets given that market segmentation induces low international betas (Stulz, 1999). However, betas can increase abruptly during international crisis periods due to multiple economic interconnections and psychological factors (Bekaert, Harvey and $\mathrm{Ng}$, 2005). This can lead to an increase in the cost of capital. Such variations can destabilize the financial system given that discount rates determine the value of real and financial assets, the expected Net Present Value for investment projects, and affects most wealth allocation decisions.

\section{Data and methodology}

\subsection{Data}


This study focuses on the five largest ASEAN economies: Indonesia, Thailand, Malaysia, Singapore and the Philippines. We use local daily stock market index in local currencies in order to cover total market capitalization and to neutralize potential biases arising from exchange rate dynamics. The initial dataset ranges from $2007 / 4 / 1$ to $2010 / 11 / 1$ and is used to derive monthly indicators of microstructures.

\subsection{Market microstructure}

\subsubsection{Efficiency $(k)$}

We monitor time-varying efficiency levels via an explicit random walk modelling framework developed in Emerson et.al (1997).

$r_{t}=\beta_{0 t}+\sum_{i=1}^{p} \beta_{i t} r_{t-i}$

Where $r$ denotes returns and $t$ is the time subscript. Controlling for changing variance in the error process, they combined the above specification with a GARCH-in-mean model:

$$
\begin{aligned}
& r_{t}=\beta_{0 t}+\sum_{i=1}^{p} \beta_{i t} r_{t-i}+\partial h_{t}+e_{t} \quad e_{t} \sim \mathrm{N}\left(0, \mathrm{~h}_{\mathrm{t}}\right) \\
& h_{t}=\alpha_{0}+\alpha_{1} h_{t-1}+\alpha_{2} e_{t-1}
\end{aligned}
$$

This model is then estimated via the following Kalman filter procedure:

$$
\begin{aligned}
& r_{t}=\beta_{0 t}+\sum_{i=1}^{p} \beta_{i t} r_{t-i}+\partial h_{t}+e_{t} \quad e_{t} \sim \mathrm{N}\left(0, \mathrm{~h}_{\mathrm{t}}\right) \\
& h_{t}=\alpha_{0}+\alpha_{1} h_{t-1}+\alpha_{2} e_{t-1} \\
& \beta_{i t}=\beta_{i t-1}+v_{i t} \quad v_{i t} \sim \mathrm{N}\left(0, \sigma_{\mathrm{i}}^{2}\right)
\end{aligned}
$$


Where (3a) is the space equation and (3b) and (3c) are the two state equations, respectively. In equation (3c), $\beta_{i t}$ tracks time-varying deviations from the random walk. We estimate the model over the entire sample and then use the monthly average of $\beta_{i t}$ (taken in absolute value) as an indicator of relative market inefficiency for each country.

\subsubsection{Volatility (garch)}

We give a formal structure to the evolution of stock market volatility using a GARCH $(1,1)$ specification. We then use annual average predicted variance of daily returns as an indicator of equity market volatility. The model is described as follows:

$r_{t}=\alpha+\beta r_{t-1}+e_{t-1}$

$\sigma_{t}^{2}=\delta+\gamma_{1} \sigma_{t-1}^{2}+\gamma_{2} e_{t-1}$

In (4), the first equation describes the stock return mean $r_{t}$ which depends on a constant, its lagged value and i.i.d residual $e_{t-1}$. The second equation describes the variance of the error term, which has three components: a constant, the last period's variance (the GARCH term), and the last period's squared residual (the $\mathrm{ARCH}$ term). The unit variance assumption for the innovation process, $e_{t-1}$, ensures that $\sigma_{t}^{2}$ is the variance of $r_{t}$, depending on the information set, $F_{t-1}$, that contains the past history of the process up to period $t-1$. Volatility is then aggregated at the monthly level.

\subsubsection{Transaction costs (dni)}

Roll (1984) and Kyle (1985) showed that the structure of auto-covariance in stock market returns tracks the evolution of illiquidity levels. Taking this into account, De Nicolò and Ivaschenko (2009) captured market frictions based on a simple decomposition of return variance. For a given time horizon $t$ divided in $K$ trading day and s subintervals, returns at time t satisfy: 


$$
\begin{aligned}
& R_{t}=\sum_{s \in K} R_{s} \\
& \operatorname{Var}_{t}\left(R_{t}\right)=\sum_{s \in K} \operatorname{Var}\left(R_{s}\right)+2 \sum_{i, j \in K, i \neq j} \operatorname{Cov}\left(R_{i}, R_{j}\right)
\end{aligned}
$$

The magnitude of the auto-covariance term in equation (5) reflects the presence of transaction costs and market frictions. In the next step, a transaction costs indicator is constructed:

$$
L_{t}=\frac{2\left(\sum_{i, j \in K, i \neq j} \operatorname{cov}\left(R_{i}, R_{j}\right)\right)}{\sum_{s \in K} \operatorname{var}_{t}\left(R_{s}\right)+2\left(\sum_{i, j \in K, i \neq j} \operatorname{cov}\left(R_{i}, R_{j}\right)\right)}
$$

Where $\mathrm{K}$ is the annual horizon, $\mathrm{i}$ and $\mathrm{j}$ denote daily observations. Covariances and variances are estimated from a $\operatorname{GARCH}(1,1)$ model. Absolute values are used in order to capture all possible sources of market frictions. The indicator ranges from 0 to 1 and increases with transaction costs. This indicator is calculated on a monthly basis.

\subsubsection{Equity market integration (akdo)}

We use a time-varying risk-decomposition model in order to monitor country exposure to international shocks on equity markets. We begin with a standard asset pricing model:

$$
R_{i}=\alpha+\beta R_{g}+\varepsilon_{i}
$$

Where $R_{i}$ is the rate of return on the $\mathrm{i}^{\text {th }}$ country, $R_{g}$ is the global rate of return, $b$ is the beta of the $\mathrm{i}^{\text {th }}$ country with respect to the global index, and $\varepsilon_{i}$ is the error term. Following Akdogan (1997), the variance of country returns can then be broken down into:

$$
\operatorname{Var}\left(R_{i}\right)=\beta^{2} \operatorname{Var}\left(R_{g}\right)+\operatorname{Var}\left(\varepsilon_{i}\right)
$$


$\frac{\operatorname{VarR}_{i}}{\operatorname{VarR}_{i}}=\frac{\beta^{2} \operatorname{VarR}_{g}}{\operatorname{VarR}_{i}}+\frac{\operatorname{Var}_{i}}{\operatorname{VarR}_{i}}$

$1=p_{i}+q_{i}$

In equation (15), $p_{i}$ measures the country's exposure to worldwide systemic risk. This score is calculated on a monthly basis and constitutes a time-varying indicator of international exposure.

\subsection{The structural VAR model}

The representation of the reduced form of the vector auto-regression model $\operatorname{VAR}(q)$ is

$Y_{t}=\sum_{i=1}^{q} A_{i} Y_{t-i}+e_{t}$

Where $q$ is the number of lags, $e_{t}$ is a white noise. In order to simplify the representation, the variables are divided into two blocks: $y_{1 t}$ represents the exogenous variable and $y_{2 t}$ the domestic variables. The error vector's variance-covariance matrix has no restrictions, that is to say $E\left(e_{t}, e_{t}^{T}\right)=\Omega$ and $E\left(e_{t}\right)=0 . L$ is the lag operator. Consequently, the $\operatorname{VAR}(q)$ model can be written as:

$A(L) Y_{t}=e_{t}$

In order to obtain the shock response functions and the forecast error variance decomposition, this process is written in a Moving Average infinite structural form. An intermediate step consists in "reversing" the canonical VAR model according to the Wold Theorem so as to obtain its moving average form:

$Y_{t}=\sum_{j=0}^{\infty} C_{j} e_{t-j}=C(L) e_{t}$ 
where $e_{t}$ represents the vector of canonical innovations.

Thus, the structural Moving Average representation is:

$$
\begin{gathered}
Y_{t}=\sum_{j=0}^{\infty} \Theta_{j} \varepsilon_{t-j}=\Theta(L) \varepsilon_{t} \\
\text { with } \quad e_{t}=P \varepsilon_{t}
\end{gathered}
$$

where $P$ is an invertible matrix $n \times n$ which has to be estimated in order to identify the structural shocks. The short-run constraints are imposed directly on $P$ and correspond to some elements of the matrix that are set to zero. The $\Theta_{j}$ matrix represents the response functions to shocks $\varepsilon_{t}$ of the elements of $Y_{t}$. The different structural shocks are assumed to be noncorrelated and to have a unitary variance:

$E\left(\varepsilon_{t}, \varepsilon_{t}^{T}\right)=I_{n}$

$\Omega$ is the variance-covariance matrix of the canonical innovations $e_{t}$, thus :

$E\left(e_{t}, e_{t}^{T}\right)=P E\left(\varepsilon_{t}, \varepsilon_{t}^{T}\right) P^{T}=P P^{T}=\Omega$

In our model, the financial sector of each economy is described by the following vector of endogenous variables:

$Y=\left(\begin{array}{c}\text { world_garch } \\ k \\ \text { garch } \\ \text { akdogan } \\ \text { dni }\end{array}\right)$

The first variable is a positive shock of volatility of the United States' stock exchange index $(S \& P 500) . k$ represents the informal efficiency on the domestic financial market, garch is the domestic financial market volatility variable, akdo the variable of domestic financial market integration and $d n i$ is domestic financial market liquidity indicator. 
The variables are used in logarithm and are seasonally adjusted. Given that Bayesian inference is used, the model is not then affected by the presence of a unit root following the postulate of Sims (1988) and Sims and Uhlig (1991). The structural disturbances vector linked to each variable is then:

$\varepsilon_{t}=\left(\begin{array}{c}\varepsilon_{\text {world_vol }} \\ \varepsilon_{e f f} \\ \varepsilon_{v o l} \\ \varepsilon_{\text {int }} \\ \varepsilon_{\text {liq }}\end{array}\right)$

Where $\varepsilon_{\text {world } \_ \text {vol }}, \varepsilon_{\text {eff }}, \varepsilon_{\text {vol }}, \varepsilon_{\text {int }}, \varepsilon_{\text {liq }}$, represent international financial markets, informational efficiency, domestic market volatility, international integration and liquidity shocks, respectively.

\subsection{The contemporaneous restrictions}

The purpose of the study is to analyze the short term financial impact of the crisis. Therefore, the impact of the disturbances has been reduced to 9 months. We thus only impose contemporaneous restrictions and use the Bayesian procedure proposed by Sims and Zha (1995, 1999). Our objective is to identify the $n^{2}$ elements of the $P$ matrix. The $\Omega$ matrix is symmetric, consequently $n(n+1) / 2$ orthogonalization constraints are already imposed. We determine the ten remaining constraints using the Choleski decomposition.

\section{Results and discussion}

\subsection{Impulse response functions and variance decomposition analysis}

Impulse response functions show the reaction of domestic variables to a one-standarddeviation positive variation of the external variable. Responses are significant if the 
confidence interval does not include the horizontal axis ${ }^{4}$. Inspection of figures 1 to 5 shows that global volatility exerts a significant impact on time-varying microstructures. More particularly, global shocks have a negative short run impact on efficiency levels $(k)$ in Thailand, Indonesia, Malaysia and the Philippines. This drop in efficiency is accompanied by a volatility jump (garch) in Thailand, Indonesia, the Philippines and Singapore, while exposure to systematic risk (akdogan) increases in all countries. In all cases, the impact tends to occur 1 or 2 months after the initial shock and disappear within the next 5 months.

\section{INSERT FIGURES 1 to 5 ABOUT HERE}

Turning to variance decomposition analysis, global volatility appears to explain up to $70 \%$, $54 \%, 45 \%, 51 \%$ of Thailand's, Indonesia's, Philippines' and Singapore's volatility, in most cases in the immediate aftermath of the crisis. This clearly suggests the presence of international financial shocks vulnerability. By contrast, in Malaysia the global shock only explains $3 \%$ of market volatility, suggesting that restrictive measures were efficient in containing turmoil transmission. The efficiency variable $(k)$ is strongly altered by global shocks, with scores of $18 \%, 65 \%, 16 \%, 47 \%$, and $29 \%$ for Thailand, Indonesia, Malaysia, the Philippines and Singapore, respectively. The integration variable (akdogan) is relatively less affected, with VDA scores of $9.2 \%, 4.3 \%, 7.6 \%, 14 \%$ and $17.5 \%$ for Thailand, Indonesia, Malaysia, the Philippines and Singapore, respectively. Finally, illiquidity levels (dni) are also relatively stable, with maximum VDA scores of $9.1 \%, 9.2 \%, 4.4 \%, 29 \%$ and $19.6 \%$ for Thailand, Indonesia, Malaysia, the Philippines and Singapore, respectively.

\section{INSERT TABLES 1 TO 5 ABOUT HERE}

\footnotetext{
${ }^{4}$ Following Sims and Zha (1999), error bands correspond to the $0.16 \%$ and $0.84 \%$ fractiles, i.e. a confidence interval of $68 \%$.
} 


\subsection{Shock asymmetries, restrictions and institutional framework}

We uncover strong cross-country asymmetries. In particular, two stock markets (Malaysia and Singapore) resisted the crisis. In Malaysia, capital market institutions improved dramatically during the past ten years with the implementation of a Capital Market Master Plan in 1999, which significantly improved regulatory framework and corporate governance, while fostering the development of derivative markets and the stock broking industry. These institutional trends may explain why in spite of a deviation in efficiency $(k)$ and systematic risk exposure (akdogan), the Malaysian stock exchange resisted the crisis well overall, as volatility levels (garch) were stable throughout the period.

Singapore constitutes another example of market resilience: volatility (garch) increased following the global shock, but efficiency levels $(k)$ were unchanged and the impact of global volatility on systematic risk exposure (akdogan) was negative. The absence of sharp microstructure destabilization may reflect the country's high level of financial development. Singapore indeed adopted a gradual internationalization strategy backed by strong prudential supervision in order to promote competition and efficiency in the financial industry and ultimately position the country as a global financial hub. These efforts are reflected in Singapore's $4^{\text {th }}$ rank in global financial development in the World Economic Forum's 2010 benchmark. Finally, resilience may also be explained by fast and decisive public intervention. The Monetary Authority of Singapore (MAS) indeed implemented a US Dollar swap facility with the US Federal Reserve in October 2008 to reassure financial institutions that they would have access to international liquidity. The government also announced a guarantee on the deposits of individuals and non-bank customers of banks licensed in Singapore, thereby signaling the soundness of the financial sector.

By contrast, microstructures of the Indonesian, Thai and Philippines stock markets were significantly altered by the global crisis, as efficiency levels (k), volatility ( $\operatorname{arch}$ ) and 
systematic risk exposure (akdogan) were all adversely impacted. These countries' financial systems are characterized by a combination of international capital restrictions and relatively poor institutional quality.

In Thailand, foreign participation is restricted to $49 \%$ of the registered capital, with a $25 \%$ participation ceiling in insurance, banking and securities companies. The number of foreign shareholders must also be less than half of the total number of shareholders for a given company. In Indonesia, cross border supply and consumption of financial services is forbidden, and foreign brokers must establish a local company to operate, while foreign equity participation is restricted to $49 \%$ of registered capital for bank and non-finance listed companies. Finally, Philippines are one of the world's most restrictive environments for foreign investors according to the World Bank's Investing Across Border 2010 report. For instance, foreign participation in strategic sectors such as oil and gas industries, telecommunications, electricity, transportation, and media is restricted to a maximum of $40 \%$. This suggests that microstructural destabilization is not related to foreign investment liberalization, but depends instead on the domestic investors' cognitive model.

Turning to institutional quality, the Indonesian market displays extreme concentration of ownership, a family-oriented capitalism (two third of public companies classified as familyowned), and very limited number of minority shareholders. These factors provide constraints on market forces as governance, and result in low liquidity and wrong prices, whose deviations from equilibrium value can be exacerbated in times of informational stress. In the Philippines, the primary dealers network is inadequate, the repurchase market is underdeveloped, and the absence of bid and offer price quotations as well as limitations in regulations (including disclosure requirements and supervision) undermine the efficiency of secondary markets. Generally, the market infrastructure needs strengthening to improve liquidity and transparency. Finally, in spite of improvement during the past decade, a number 
of unaddressed issues undermine in the Thai capital market's economic role: an insufficient number of institutional investors, small retail investor base, limited financial products, high transaction costs and lack of efficient regulatory enforcement. An increasing awareness of these issues led to the creation of the Capital Market Development Committee in 2009.

\subsection{Policy implications}

Our results echo previous discussion on the inaccuracy of market restrictions when countries are faced with waves of 'pure contagion'. In this case, shocks are imported by cognitive adjustments of domestic investors rather than through market linkages (Athukorala and Warr, 2002). In other words, financial destabilization does not stem only from the behavior of foreign market players but operates through an endogenous shift in domestic investor's set of beliefs. Our findings also suggest that this type of vulnerability is associated with poor institutional structure, and that it can be mitigated through regulatory improvement. In this respect, extending the Asian Bond Initiative to capital market consolidation would be useful. This would permit to reinforce regional resilience, diminish asymmetries in shock vulnerability levels, and enhance overall regional integration.

However, equity market development carries a 'residual' destabilization risk which appears uncorrelated to institutional quality. This is reflected in the fact that Malaysian and Singaporean microstructures significantly impacted by the crisis, in spite of modern market structure and bye-laws. This finding is in line with the literature on market imperfections, which highlights that even the more liquid and mature markets are subject to market failure due to the persistence of asymmetric information and behavioural biases (Stiglitz and Weiss, 1981). Suitable government intervention in capital markets and in the economy may therefore be necessary to mitigate these pervasive effects. 
Finally, microstructure vulnerability needs to be analyzed in relation to real sector trends. Malaysia, Thailand, and the Philippines suffered from the crisis in 2009, with economic growth rates of $-1.7 \%$ in Malaysia, $-2.3 \%$ in Thailand and a deceleration from $7.1 \%$ in 2007 to 0.9\% in 2009 for the Philippines. However, we should note that in spite of significant microstructure destabilization, Indonesia posted a positive $4.4 \%$ growth rate in 2009 . This could be explained by the low macroeconomic impact of the stock market, with a market capitalization to GDP ratio of $18 \%$ in 2008 , and the presence of more than 100 state-owned enterprises in the economy. Concurrently, Singapore registered a -1.3\% GDP growth in 2009, in spite of a mild microstructure destabilization. This suggests that real economic linkages and international risk exposure determine crisis vulnerability, regardless of the quality of market microstructures. From a policy point of view, strategic macroeconomic coordination should therefore be prioritized over microeconomic reforms.

\section{Conclusion}

This paper investigated the impact of the ongoing financial crisis on stock market microstructures in Malaysia, Thailand, Singapore, Indonesia and the Philippines. Using daily stock market data from 2007 to 2010, we first developed a set of monthly liquidity, efficiency, international integration and volatility indicators for each country. We then analyzed the impact of time-varying global market volatility on those indicators, using a set of Bayesian SVAR models. Forecast error variance decomposition analysis and impulse response function allowed identifying the magnitude and the symmetry of local financial systems exposures to international shocks. Overall, we found that global volatility shocks significantly altered the dynamics of microstructure in this region. We also highlighted significant shock asymmetries, which appeared to depend on the quality of regulatory structures as well as on a residual psychological mechanism. Finally, our results also suggest that real economic linkages 
constitute the most important source of crisis contagion. From a policy perspective, future regional integration initiatives should thus seek to (i) contain fundamental contagion vulnerability, (ii) rethink the role allocated to banks, governments and capital markets in development financing, and (iii) improve stock market structure and institutions. Inserting these issues in the negotiation agenda could serve as a basis for enhanced economic integration, shock resilience and economic welfare in the ASEAN region.

\section{References}

Akdogan, H, 1997. International security selection under segmentation: theory and application. Journal of Portfolio 21, 33-40.

Allen, A., Gale, D., 1994. Limited market participation and volatility of asset prices. The American Economic Review 84, 933-955.

Athukorala, P., Warr, P.G., 2002. Vulnerability to a currency crisis: lessons from the Asian experience. The World Economy 25, 33-57.

Bekaert, G., Harvey, C. R., Ng, A., 2005. Market Integration and Contagion. Journal of Business 78, 39-70.

Carhart, M. M, 1997. On persistence in mutual fund performance. Journal of Finance 52, 57 82.

Chang R., Velasco A., 2000. Banks, debt maturity and financial crises. Journal of International Economics 51, 169-194.

Committee on Global Financial Stability, 2009. Capital flows and emerging market economies. January, No 33.

Corsetti, G., Pesenti, P., Roubini, N., 1999. Paper tigers? A model of the Asian crisis. European Economic Review 43, 1211-1236.

De Nicolò, G., Ivaschenko, I., 2009. Global liquidity, risk premiums and growth opportunities. CESIFO Working Paper No. 2598

Emerson, R., Hall, S.G., Zalewska-Mitura, A., 1997. Evolving market efficiency with an application to some bulgarian shares. Economics of Planning 30, 75-90.

Kaminsky, G.L., Reinhart, C.M., Vegh, C.A., 2003. The unholy trinity of financial contagion. Journal of Economic Perspectives Fall, 51-74.

Kyle, A., 1985. Continuous auctions and insider trading. Econometrica 53, 1315-1335.

Lagoarde-Segot, T., 2009. Financial reforms and time-varying microstructures in emerging equity markets. Journal of Banking and Finance 33, 1755-1769.

Mohan, R., Kapur, M., 2010. Liberalization and regulation of capital flows: lessons for emerging market economies. Asian Development Bank Institute Working Paper Series, No.186.

Roll, R, 1984. A simple implicit measure of the effective bid-ask spread in an efficient market. Journal of Finance 39, 1127-1140.

Schaller, H., Chirinko, R., 2001. Business fixed investment and 'bubbles': The Japanese case. American Economic Review, 3-91, 3, 663-680. 
Schill, M.J., 2004.Sailing in rough waters: market volatility and corporate finance. Journal of Corporate Finance 10, 659-682.

Sims C.A., 1988. Bayesian skepticism on unit root econometrics. Journal of Economic Dynamics and Control 12, 463-474.

Sims C.A., Uhlig, H., 1991. Understanding unit rooters: a helicopter tour. Econometrica 59, 1591-1599.

Stiglitz, J.E, Weiss, A., 1981. Credit rationing in markets with imperfect information. American Economic Review 71, 393-410.

Stulz, R., 1999. Globalization, corporate finance and the cost of capital. Journal of Applied Corporate Finance 12, 8-25. 
Table 1 Variance decomposition analysis: Thailand

\begin{tabular}{|c|c|c|c|c|}
\hline Month & $\mathrm{k}$ & garch & akdo & dni \\
\hline 1 & 10.334 & 70.367 & 1.559 & 0.168 \\
\hline 2 & 13.393 & 66.642 & 6.378 & 0.321 \\
\hline 3 & 14.900 & 65.143 & 7.937 & 8.425 \\
\hline 4 & 16.405 & 65.134 & 7.908 & 8.310 \\
\hline 5 & 17.465 & 63.833 & 8.938 & 7.985 \\
\hline 6 & 17.895 & 63.424 & 9.071 & 8.589 \\
\hline 7 & 17.982 & 62.997 & 9.153 & 8.818 \\
\hline 8 & 18.001 & 62.463 & 9.191 & 8.906 \\
\hline 9 & 18.035 & 62.107 & 9.193 & 9.007 \\
\hline 10 & 18.039 & 61.771 & 9.218 & 9.105 \\
\hline
\end{tabular}

Table 2 Variance decomposition analysis: Indonesia

\begin{tabular}{|c|c|c|c|c|}
\hline Month & $\mathrm{k}$ & garch & akdo & dni \\
\hline 1 & 21.893 & 13.439 & 2.526 & 0.370 \\
\hline 2 & 53.519 & 46.616 & 3.013 & 1.303 \\
\hline 3 & 65.877 & 54.979 & 2.745 & 7.861 \\
\hline 4 & 61.894 & 49.030 & 3.662 & 8.613 \\
\hline 5 & 55.916 & 46.554 & 4.278 & 8.865 \\
\hline 6 & 54.396 & 45.698 & 4.246 & 9.167 \\
\hline 7 & 53.949 & 45.392 & 4.220 & 9.144 \\
\hline 8 & 53.721 & 45.115 & 4.278 & 9.222 \\
\hline 9 & 53.576 & 45.200 & 4.295 & 9.237 \\
\hline 10 & 53.555 & 45.209 & 4.296 & 9.234 \\
\hline
\end{tabular}

Table 3 Variance decomposition analysis: Malaysia

\begin{tabular}{|c|c|c|c|c|}
\hline Month & $\mathrm{k}$ & garch & akdo & $\mathrm{dni}$ \\
\hline 1 & 7.282 & 1.631 & 0.009 & 0.693 \\
\hline 2 & 12.059 & 2.993 & 7.680 & 3.801 \\
\hline 3 & 11.761 & 2.700 & 7.083 & 3.351 \\
\hline 4 & 14.313 & 2.619 & 7.477 & 3.574 \\
\hline 5 & 15.208 & 3.077 & 7.170 & 4.429 \\
\hline 6 & 15.638 & 3.075 & 7.073 & 4.428 \\
\hline 7 & 15.676 & 3.067 & 7.047 & 4.415 \\
\hline 8 & 15.912 & 3.074 & 7.078 & 4.405 \\
\hline 9 & 16.032 & 3.092 & 7.067 & 4.398 \\
\hline 10 & 16.112 & 3.091 & 7.062 & 4.412 \\
\hline
\end{tabular}


Table 4 Variance decomposition analysis: Philippines

\begin{tabular}{|c|c|c|c|c|}
\hline Month & $\mathrm{k}$ & garch & akdo & $\mathrm{dni}$ \\
\hline 1 & 0.008 & 7.173 & 0.240 & 12.740 \\
\hline 2 & 4.109 & 23.083 & 0.855 & 17.054 \\
\hline 3 & 26.470 & 42.527 & 2.475 & 17.339 \\
\hline 4 & 42.753 & 39.725 & 2.685 & 26.328 \\
\hline 5 & 45.431 & 39.409 & 10.348 & 28.943 \\
\hline 6 & 45.884 & 42.202 & 10.158 & 28.295 \\
\hline 7 & 46.087 & 42.808 & 10.766 & 28.123 \\
\hline 8 & 46.243 & 43.690 & 11.639 & 27.924 \\
\hline 9 & 46.943 & 44.286 & 13.518 & 27.941 \\
\hline 10 & 47.645 & 44.262 & 14.157 & 28.471 \\
\hline
\end{tabular}

Table 5 Variance decomposition analysis: Singapore

\begin{tabular}{|c|c|c|c|c|}
\hline Month & $\mathrm{k}$ & garch & akdo & $\mathrm{dni}$ \\
\hline 1 & 5.090 & 51.647 & 0.003 & 0.004 \\
\hline 2 & 19.855 & 42.329 & 0.007 & 9.559 \\
\hline 3 & 20.669 & 36.345 & 12.747 & 19.474 \\
\hline 4 & 28.229 & 37.264 & 14.494 & 19.657 \\
\hline 5 & 28.103 & 37.889 & 13.264 & 19.294 \\
\hline 6 & 29.157 & 37.969 & 16.333 & 18.551 \\
\hline 7 & 29.053 & 38.214 & 15.204 & 18.784 \\
\hline 8 & 29.301 & 38.468 & 17.201 & 18.778 \\
\hline 9 & 29.245 & 38.437 & 16.959 & 18.762 \\
\hline 10 & 29.409 & 38.524 & 17.490 & 18.795 \\
\hline
\end{tabular}


Figure 1 Impulse response functions: Thailand

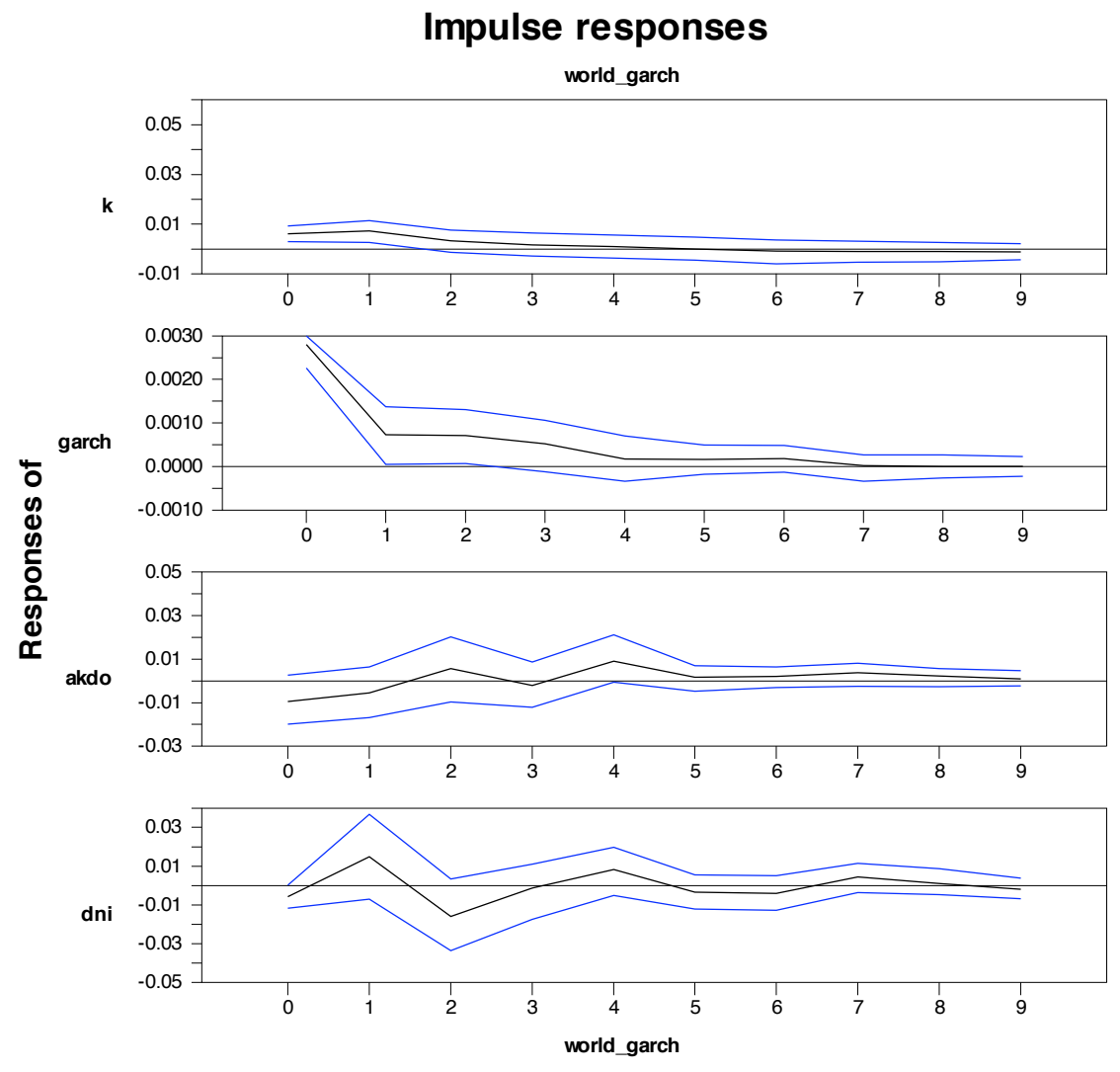


Figure 2 Impulse response functions: Indonesia

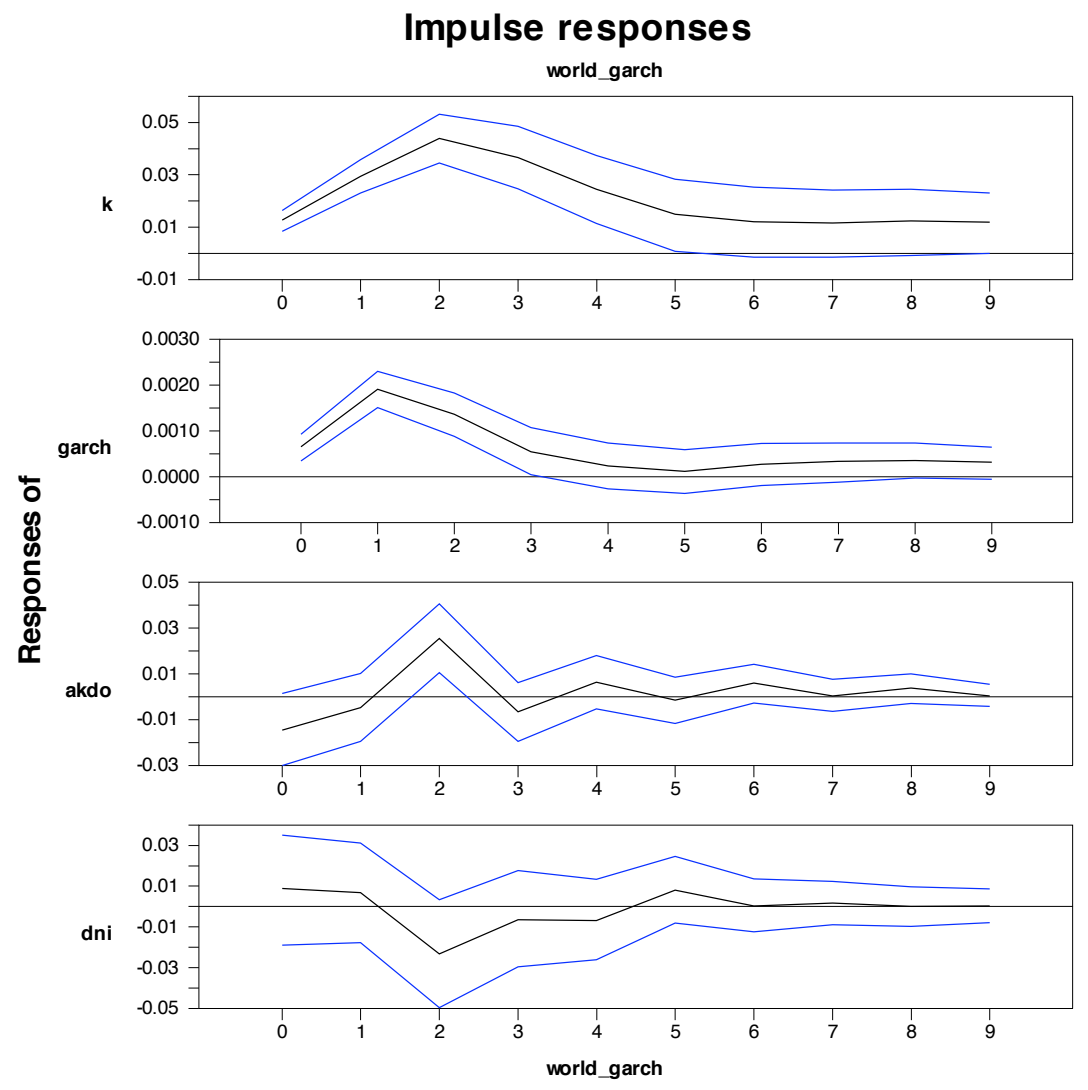


Figure 3 Impulse response functions: Malaysia

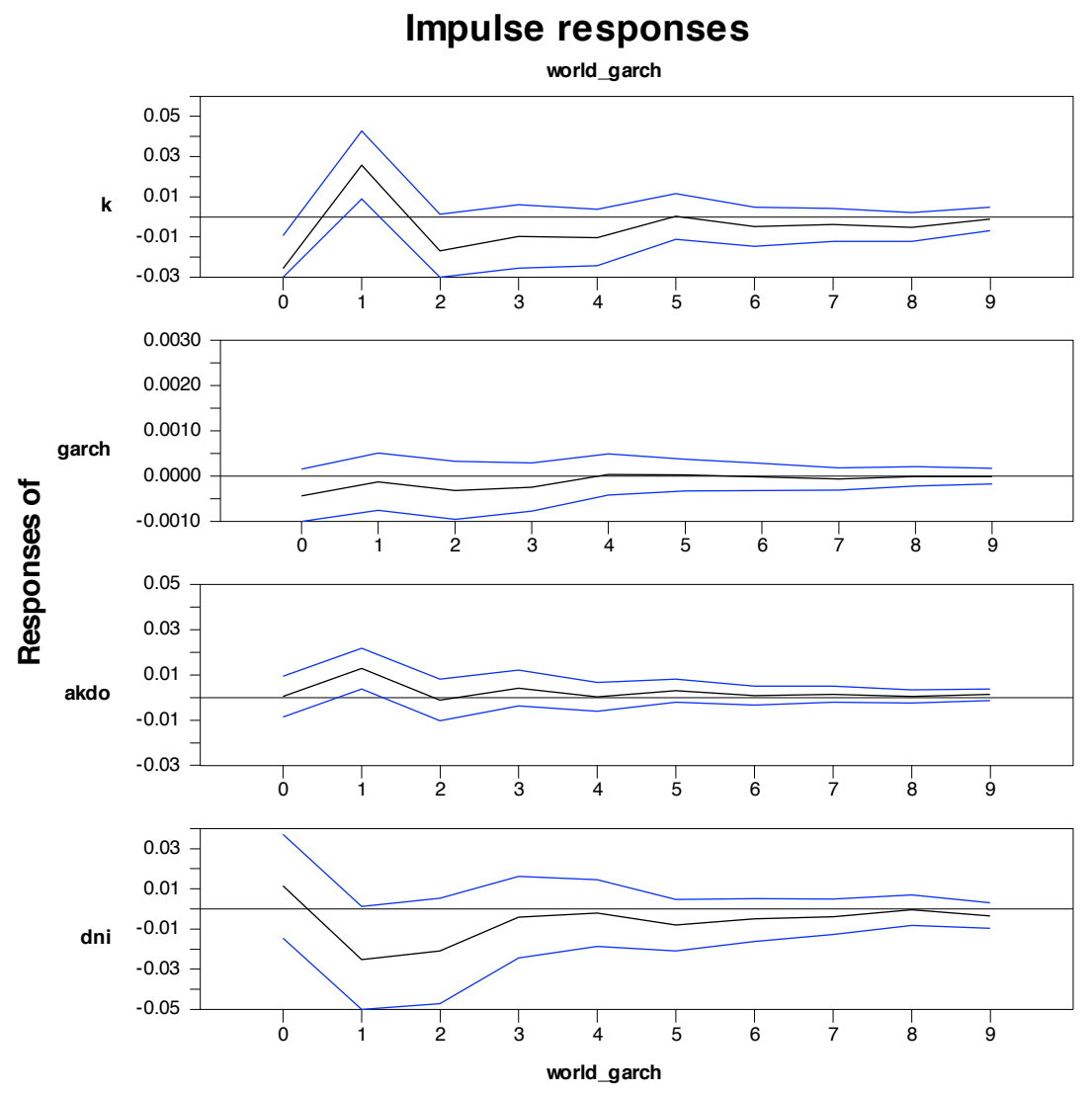


Figure 4 Impulse response functions: Philippines

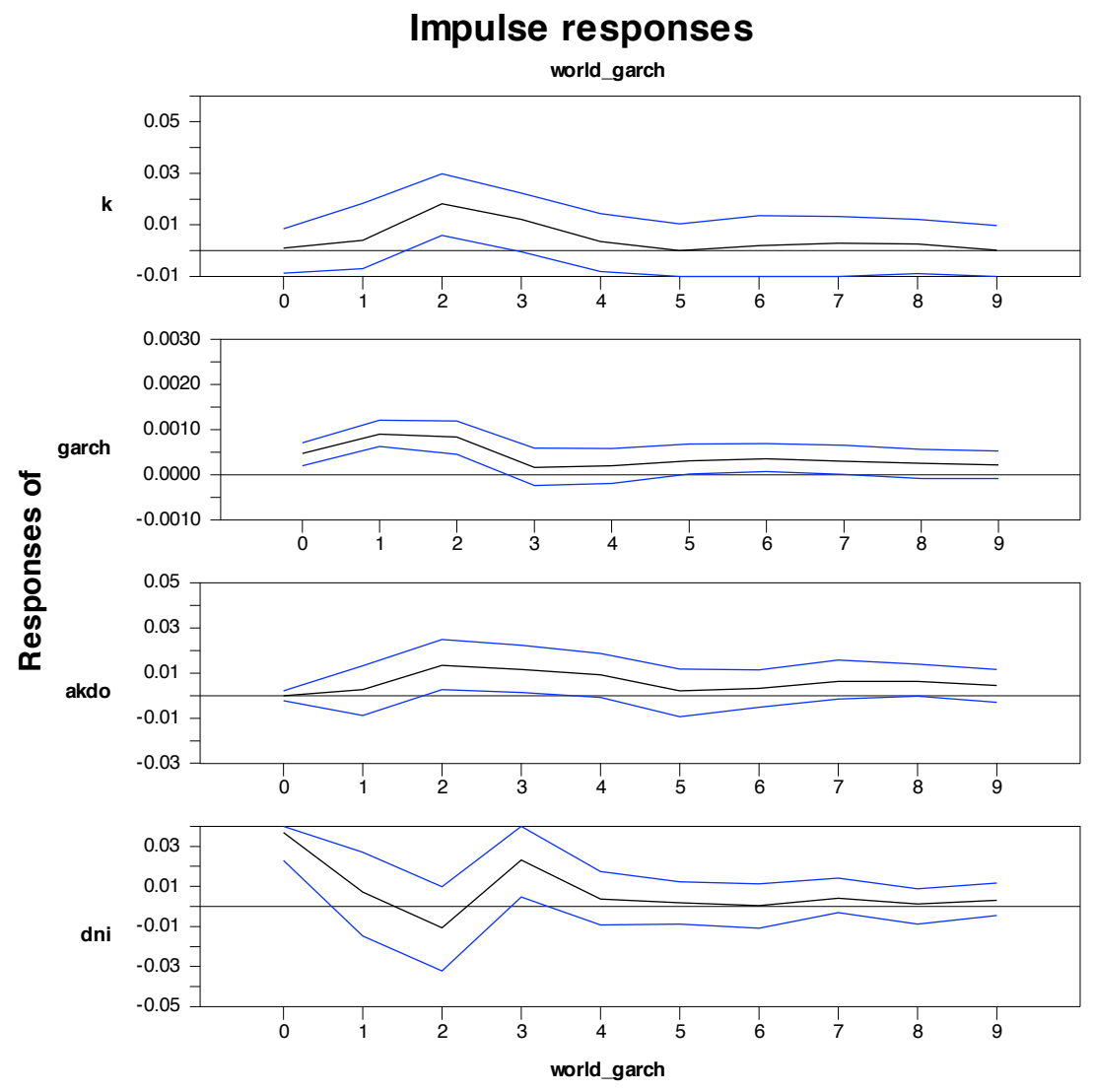


Figure 5 Impulse response functions: Singapore

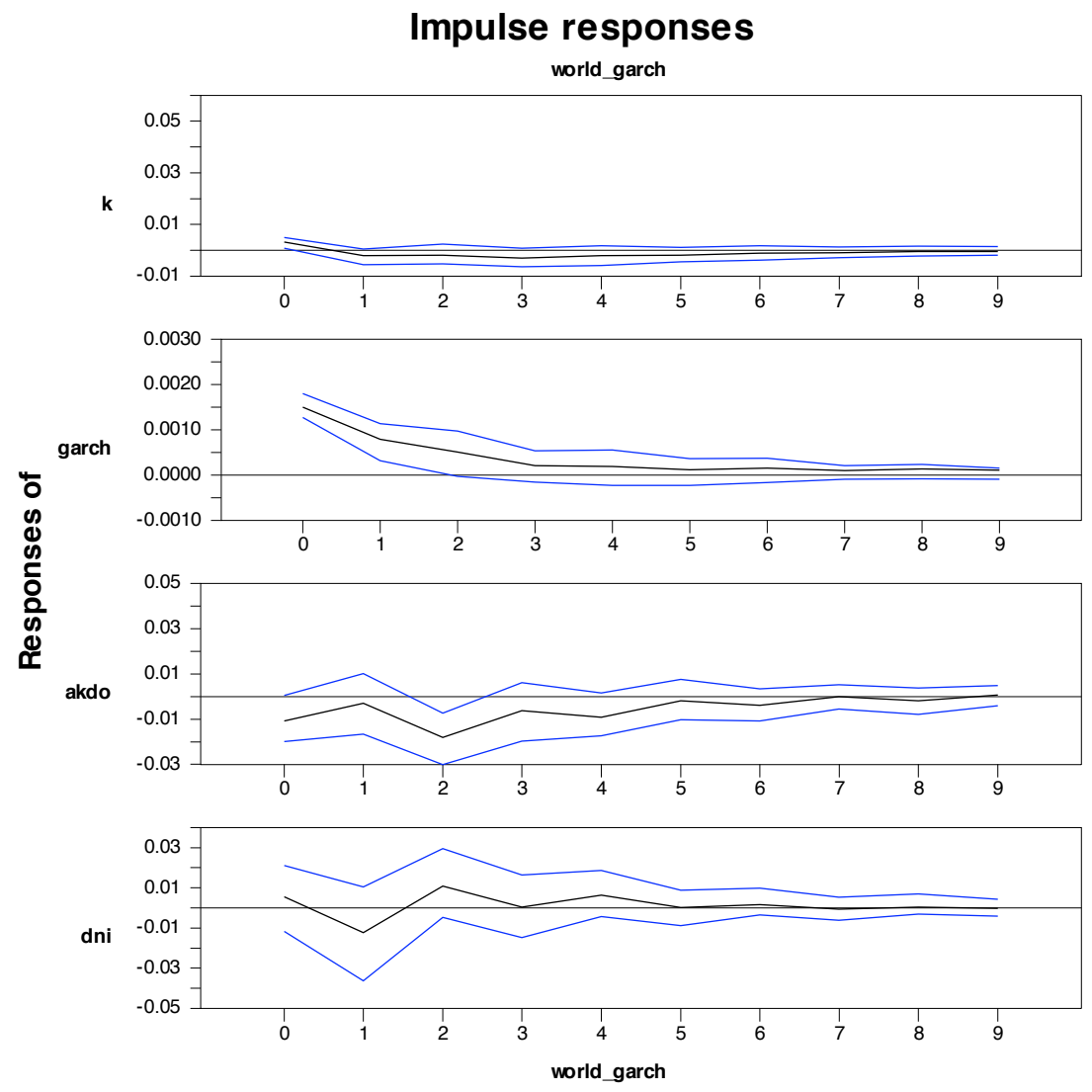




\section{Appendix 1. Rolling monthly GARCH(1,1) volatility}

\begin{tabular}{|c|c|c|c|c|c|c|}
\hline Month & Thailand & Indonesia & Malaysia & Philippines & Singapore & S\&P500 \\
\hline 2007-04 & 0.0052039 & 0.0050736 & 0.005368 & 0.0056768 & 0.0063891 & 0.0042357 \\
\hline 2007-05 & 0.0058281 & 0.0055344 & 0.0047641 & 0.0111138 & 0.0046759 & 0.0042624 \\
\hline 2007-06 & 0.0066694 & 0.0054889 & 0.0044619 & 0.0053324 & 0.0039968 & 0.0039226 \\
\hline 2007-07 & 0.0073333 & 0.0051767 & 0.0047152 & 0.0054262 & 0.0043545 & 0.005023 \\
\hline 2007-08 & 0.0109989 & 0.0053298 & 0.0048258 & 0.0060491 & 0.0046595 & 0.0059135 \\
\hline 2007-09 & 0.0070586 & 0.0047432 & 0.0056467 & 0.0050251 & 0.0066264 & 0.0051497 \\
\hline $2007-10$ & 0.0066749 & 0.012306 & 0.0052072 & 0.012978 & 0.0054959 & 0.0052028 \\
\hline 2007-11 & 0.0069243 & 0.0053412 & 0.0044968 & 0.0057521 & 0.0046606 & 0.005315 \\
\hline $2007-12$ & 0.0070319 & 0.0066542 & 0.0046678 & 0.0062803 & 0.0054989 & 0.0056236 \\
\hline 2008-01 & 0.0099064 & 0.006467 & 0.0050491 & 0.0061461 & 0.0050133 & 0.0057907 \\
\hline 2008-02 & 0.0063966 & 0.0051744 & 0.0052294 & 0.0060233 & 0.0111095 & 0.0057599 \\
\hline 2008-03 & 0.0070516 & 0.0090144 & 0.004041 & 0.0067731 & 0.0046727 & 0.0046896 \\
\hline 2008-04 & 0.0057634 & 0.0062087 & 0.0071504 & 0.0052891 & 0.0051655 & 0.0076578 \\
\hline 2008-05 & 0.0067495 & 0.0106121 & 0.0047165 & 0.0065293 & 0.0045478 & 0.0047727 \\
\hline 2008-06 & 0.0070761 & 0.0056475 & 0.0044748 & 0.005106 & 0.0045989 & 0.0049273 \\
\hline 2008-07 & 0.0080511 & 0.0058183 & 0.0051155 & 0.0062558 & 0.0054634 & 0.0058303 \\
\hline 2008-08 & 0.0066747 & 0.0055215 & 0.0046825 & 0.006169 & 0.0043682 & 0.0054684 \\
\hline 2008-09 & 0.008015 & 0.0061514 & 0.0048353 & 0.0056898 & 0.0076231 & 0.0055052 \\
\hline 2008-10 & 0.026254 & 0.0083245 & 0.0052892 & 0.0079667 & 0.0157736 & 0.0249215 \\
\hline 2008-11 & 0.0118071 & 0.0193834 & 0.0060313 & 0.0117267 & 0.0097554 & 0.0157921 \\
\hline 2008-12 & 0.0142229 & 0.0196639 & 0.0047289 & 0.0129666 & 0.0078611 & 0.0179004 \\
\hline 2009-01 & 0.0110392 & 0.0097812 & 0.0050125 & & 0.00 & 0.006374 \\
\hline 2009-02 & 0.0058665 & 0.0066092 & 0.0044023 & 0.00 & & 0.0110251 \\
\hline 2009-03 & 0.007521 & 0.0053747 & 0.00 & & 0.00 & 0.0104273 \\
\hline 2009-04 & 0.0070306 & 0.0065837 & 0.00509 & & 0.0 & 0.0074587 \\
\hline 2009-05 & 0.0093533 & 0.0083162 & 0.00468 & 953 & 0.0 & 0.0069841 \\
\hline 2009-06 & 0.0098812 & 0.0080787 & 0.0048 & 728 & 0.0 & 0.0055168 \\
\hline 2009-07 & 0.0077142 & 0.0076155 & 0.0048345 & 277 & 0.0 & 0.0061473 \\
\hline 2009-08 & 0.0071085 & 0.0065863 & 0.0046081 & 0.00 & 0.00 & 0.0050261 \\
\hline 2009-09 & 0.00623 & 0.0064709 & 0.0046767 & 0.0073537 & 0.00 & 0.0047495 \\
\hline 2009-10 & 0.0086647 & 0.0052268 & 0.0128879 & 0.0056148 & 0.00 & 0.0044245 \\
\hline 2009-11 & 0.0086329 & 0.0057303 & 0.00444 & 0.0052277 & 0.0042634 & 0.0055572 \\
\hline 2009-12 & 0.007094 & 0.0055888 & 0.0046096 & 0.0054699 & 0.0042318 & 0.0045935 \\
\hline 2010-01 & 0.0063087 & 0.0050242 & 0.004147 & 0.0043736 & 0.0037897 & 0.0043675 \\
\hline 2010-02 & 0.0057087 & 0.0048211 & 0.0263137 & 0.0054275 & 0.004081 & 0.0044818 \\
\hline 2010-03 & 0.006514 & 0.0057883 & 0.0048658 & 0.0056819 & 0.0043623 & 0.0045602 \\
\hline 2010-04 & 0.0077934 & 0.0058064 & 0.0045381 & 0.0054903 & 0.0041607 & 0.0041674 \\
\hline 2010-05 & 0.0080319 & 0.0058416 & 0.0042906 & 0.0056066 & 0.0048639 & 0.0078174 \\
\hline 2010-06 & 0.008004 & 0.0068741 & 0.0047845 & 0.0057507 & 0.0043502 & 0.0066211 \\
\hline 2010-07 & 0.0059829 & 0.0049872 & 0.0045475 & 0.0129419 & 0.0037836 & 0.0055183 \\
\hline 2010-08 & 0.0066087 & 0.0052143 & 0.0044208 & 0.00487 & 0.0037705 & 0.0046443 \\
\hline 2010-09 & 0.0075608 & 0.0059225 & 0.0048689 & 0.0057434 & 0.0043256 & 0.0053235 \\
\hline 2010-10 & 0.0039962 & 0.0032009 & 0.0029409 & 0.0033795 & 0.0026853 & 0.0030304 \\
\hline
\end{tabular}

Note: this table shows estimated monthly country volatility from a GARCH( $(1,1)$ model. 
Appendix 2. Rolling systematic risk exposure

\begin{tabular}{|c|c|c|c|c|c|}
\hline Month & Thailand & Indonesia & Malaysia & Philippines & Singapore \\
\hline 2007-04 & .0007473 & .0216438 & .0018556 & .0049018 & .0737598 \\
\hline 2007-05 & .0029482 & .1047446 & .0378226 & .0000127 & .0013517 \\
\hline 2007-06 & .040671 & .1173668 & .0037779 & .0485419 & .0010707 \\
\hline 2007-07 & .0351048 & .0546197 & .160466 & .3213816 & .085151 \\
\hline 2007-08 & .0672527 & .0030282 & .0208043 & .0730048 & .0162141 \\
\hline 2007-09 & .276585 & .0069741 & .0626258 & .0285631 & .0024153 \\
\hline 2007-10 & .0446409 & .0497297 & .0802698 & .0982925 & 0390755 \\
\hline 2007-11 & .003485 & .0741335 & .0072533 & .0049801 & .1562958 \\
\hline 2007-12 & .0064518 & .1267686 & .002993 & .0376663 & .0465083 \\
\hline 2008-01 & .0207911 & .0087973 & .0001016 & .0296799 & .0009019 \\
\hline 2008-02 & .0211845 & .1127207 & .0807527 & .1831353 & .0450722 \\
\hline 2008-03 & .0116598 & .3325892 & .0002197 & .0132209 & .0142465 \\
\hline 2008-04 & .0009243 & .0420166 & .0001006 & .0141887 & $7.29 \mathrm{e}-06$ \\
\hline 2008-05 & .0065793 & .005812 & .0006317 & .0083367 & .0105812 \\
\hline 2008-06 & .0077679 & .0580053 & .0770161 & .0049539 & .0117601 \\
\hline 2008-07 & .0016274 & .0794208 & .0372014 & .0042072 & .1355661 \\
\hline 2008-08 & .0010339 & .031211 & .082966 & .0157454 & . 10502 \\
\hline 2008-09 & .0770399 & .0224638 & .0198635 & .1638958 & .1263612 \\
\hline $2008-10$ & .0145234 & .0000402 & .0102454 & .0036921 & .008905 \\
\hline 2008-11 & .0025164 & .0149565 & .141914 & .0993352 & .0266839 \\
\hline 2008-12 & .0394175 & .2585821 & .017904 & .2223256 & .0004168 \\
\hline 2009-01 & .0015827 & .0373526 & .0000983 & .0537784 & .0000323 \\
\hline 2009-02 & 1160791 & .0144532 & .0957189 & .0796383 & .0023825 \\
\hline 2009-03 & .0000246 & .0098441 & 1967717 & .0255451 & .0602592 \\
\hline 2009-04 & .3226426 & .0086946 & .090678 & .0268642 & .0000197 \\
\hline 2009-05 & .0399931 & .3084207 & .0377653 & .0796009 & .0576227 \\
\hline 2009-06 & .0000487 & .0000787 & .1307057 & .0207726 & .0049634 \\
\hline 2009-07 & .0041011 & .1856885 & .0005323 & .0271173 & .0099169 \\
\hline 2009-08 & .1303747 & .0572574 & .0271324 & .002643 & .0020729 \\
\hline 2009-09 & .027571 & .2309527 & .0754774 & .0460388 & .0002394 \\
\hline 2009-10 & .0262501 & .0115061 & .1341186 & .0063727 & .006068 \\
\hline 2009-11 & .0122846 & .0127653 & .0424668 & .0246581 & $6.52 \mathrm{e}-06$ \\
\hline 2009-12 & .1158675 & .1200946 & .009227 & .0016886 & .0343821 \\
\hline 2010-01 & .2328591 & .006479 & .0164198 & .0190642 & .2726714 \\
\hline 2010-02 & .016118 & .0357389 & .0137978 & $4.97 \mathrm{e}-06$ & .3647371 \\
\hline 2010-03 & .0128703 & .1027423 & .0616698 & .182541 & .090116 \\
\hline 2010-04 & 1697903 & .0101056 & .005281 & .1321649 & .045437 \\
\hline 2010-05 & .0036354 & .0177256 & .0252593 & .0550045 & .0771572 \\
\hline 2010-06 & .0010898 & .0036486 & .0689625 & .0091349 & .3316671 \\
\hline 2010-07 & .0032404 & .0061981 & .0038256 & .0095541 & .0176223 \\
\hline 2010-08 & .0135025 & .0111269 & .0005309 & .0118091 & .2586571 \\
\hline 2010-09 & .0605523 & .0265919 & .0140694 & .2460475 & .0645461 \\
\hline 2010-10 & .0152367 & .008558 & .0031514 & .0780506 & .0574068 \\
\hline
\end{tabular}

Note: this table shows rolling country systematic risk exposure as estimated from Akdogan's (1996) method. 
Appendix 3. Rolling DNI illiquidity proxies

\begin{tabular}{|c|c|c|c|c|c|}
\hline Month & Thailand & Indonesia & Malaysia & Philipines & Singapore \\
\hline 2007-04 & .682727 & 6297807 & .7136673 & .6022842 & .6804072 \\
\hline 2007-05 & .6105027 & .5169642 & .4956013 & .5127254 & .6319524 \\
\hline 2007-06 & .6830174 & .6217844 & .6400388 & .6034061 & .7125777 \\
\hline 2007-07 & .6810241 & .691133 & .7703291 & .6444743 & .2862194 \\
\hline 2007-08 & .4202892 & .4588104 & .5473981 & .5542032 & .7576976 \\
\hline 2007-09 & .5520394 & .7103504 & .5644535 & .5553057 & 6457399 \\
\hline $2007-10$ & .7064604 & .5095986 & .7643555 & .3497431 & .7583168 \\
\hline $2007-11$ & .5766568 & .5209733 & .5800108 & .7704768 & .6040142 \\
\hline $2007-12$ & .6673377 & .728283 & .6390588 & .6158614 & .6340981 \\
\hline 2008-01 & .4985707 & .5451332 & .6742753 & .6413544 & .7414906 \\
\hline 2008-02 & .6459652 & .7899687 & .7193853 & .589669 & .736047 \\
\hline $2008-03$ & .5422266 & .2642182 & .7692494 & .6116467 & .5814413 \\
\hline 2008-04 & .7476934 & .7089133 & .7608908 & .7122403 & .5944159 \\
\hline $2008-05$ & .8104683 & .5753619 & .4784867 & .4248564 & .5513222 \\
\hline $2008-06$ & .315545 & 6498908 & .5040574 & .5604572 & .6085884 \\
\hline $2008-07$ & .5445664 & .4352614 & .7583561 & .6588613 & .7702483 \\
\hline 2008-08 & .7151474 & .7682887 & .7587702 & .5751508 & .7153527 \\
\hline 2008-09 & .5005379 & .787889 & 6641902 & .6213712 & .6500279 \\
\hline $2008-10$ & .5319635 & .6210606 & .6535398 & .7668008 & .5715919 \\
\hline 2008-11 & .7640588 & .5489881 & .3048529 & .7668008 & .6320795 \\
\hline $2008-12$ & .5428791 & .4376352 & .6219598 & 6949119 & .7542537 \\
\hline 2009-01 & .4752519 & .6498352 & .7101272 & .5168905 & .5899557 \\
\hline 2009-02 & 6268919 & .4253597 & .3531874 & .605792 & .7169328 \\
\hline 2009-03 & .4936341 & .7128333 & .7407117 & .5775012 & .6357214 \\
\hline 2009-04 & .650329 & .7226352 & .5556341 & .5807572 & .5198528 \\
\hline 2009-05 & .7038977 & .5497335 & .6481863 & .5470824 & .6085596 \\
\hline 2009-06 & .5073378 & .5082708 & .7152508 & .6607144 & .4959926 \\
\hline 2009-07 & 6439945 & .2085845 & 6592109 & .733772 & .6917176 \\
\hline 2009-08 & .6262733 & .623476 & .672559 & .7137641 & .5635772 \\
\hline 2009-09 & .5743552 & 6799869 & .4820452 & .8644321 & .7816161 \\
\hline 2009-10 & .5391778 & .5346631 & .5477223 & .4342985 & .7462819 \\
\hline 2009-11 & .6167859 & .5722156 & .3759318 & .6380585 & .7701014 \\
\hline 2009-12 & 6309968 & .683807 & .5630116 & .7545199 & .4947282 \\
\hline 2010-01 & .6575326 & .4749101 & .4462872 & .5181127 & .7039132 \\
\hline 2010-02 & .5054731 & .7115602 & .9355777 & .4769523 & .5834869 \\
\hline $2010-03$ & .6882668 & .5291832 & .6132158 & .7726313 & .6533144 \\
\hline 2010-04 & .7428206 & .7396216 & .610461 & .3059286 & 6792181 \\
\hline $2010-05$ & .5850207 & .6887814 & .7231417 & .7081143 & .7169779 \\
\hline $2010-06$ & .7709108 & .4705745 & .8186381 & .6744861 & .3866774 \\
\hline $2010-07$ & .8019206 & .4427118 & .5334801 & .5232757 & 6043939 \\
\hline $2010-08$ & .6474613 & .3879107 & .4401602 & .8799742 & .561598 \\
\hline 2010-09 & .6229733 & .6258898 & .8228762 & .7916943 & .5964712 \\
\hline $2010-10$ & .6229734 & .6258899 & .5598016 & .7303033 & .5964713 \\
\hline
\end{tabular}

Note: this table reports monthly illiquidity scores as developed in De Nicolò and Ivaschenko (2009) 
Appendix 4. Time-varying efficiency scores

\begin{tabular}{|c|c|c|c|c|c|}
\hline Month & Thailand & Indonesia & Malaysia & Philippines & Singapore \\
\hline 2007-04 & .0096949 & .3365017 & .5179664 & .0843607 & .1415514 \\
\hline 2007-05 & .0107411 & .2223721 & .352909 & 1014099 & .0909722 \\
\hline 2007-06 & .0114433 & .1098217 & 2094566 & .0707569 & .0496293 \\
\hline 2007-07 & .0720143 & .0632147 & .0862276 & .0253258 & 0373139 \\
\hline 2007-08 & .1132762 & .0149429 & 261964 & .0272907 & .0467242 \\
\hline 2007-09 & .0307266 & .0430144 & .1673815 & .0153235 & .0311649 \\
\hline $2007-10$ & .0306381 & .0453518 & .0864303 & .043477 & .0505368 \\
\hline 2007-11 & .0300278 & .0131736 & 1949972 & .0091357 & .070568 \\
\hline $2007-12$ & .0397129 & .0221181 & .3275719 & .0397352 & .0492204 \\
\hline 2008-01 & .0554378 & .0443778 & .4528696 & .0726909 & .0319739 \\
\hline 2008-02 & .0806129 & .0205524 & .2833042 & .0368435 & .0894853 \\
\hline 2008-03 & .0883896 & .037587 & .1173816 & .1207866 & .0755228 \\
\hline 2008-04 & .0862933 & .0484454 & .2880068 & .1249701 & .0718002 \\
\hline 2008-05 & .0899622 & .0930747 & .3206535 & .1371301 & .0654242 \\
\hline 2008-06 & .1000641 & .0967134 & .0766042 & .1389404 & 0556499 \\
\hline 2008-07 & .0998495 & .1074517 & .259853 & .1510201 & .0609038 \\
\hline 2008-08 & .0941346 & .0837279 & .1298073 & .2204368 & .0709311 \\
\hline 2008-09 & .0943858 & .0638405 & 2020359 & .1702147 & .0720684 \\
\hline $2008-10$ & 1049352 & .1361356 & .0986442 & 1449784 & .075017 \\
\hline 2008-11 & .113692 & .2366184 & .3333881 & .1153217 & .0317034 \\
\hline 2008-12 & .0933038 & .3877937 & .1293818 & .2280245 & .0320665 \\
\hline 2009-01 & .074488 & .3408189 & .1398864 & .1823579 & .0099899 \\
\hline 2009-02 & .0634784 & .1962542 & .0769662 & .0916385 & 0139997 \\
\hline 2009-03 & .0665095 & .1529517 & .1573807 & .1153225 & .0240304 \\
\hline 2009-04 & .0642195 & .1245024 & .2601455 & .1628766 & .0179882 \\
\hline 2009-05 & .0626227 & 1304792 & .1897103 & .2884339 & .0186577 \\
\hline 2009-06 & .0552223 & .1803655 & .1133618 & .2278382 & .014577 \\
\hline 2009-07 & .0531798 & .1243594 & .1732121 & .2154436 & .0161553 \\
\hline 2009-08 & .0484453 & .0552011 & .2777717 & .2515196 & .0220047 \\
\hline 2009-09 & .0466072 & .0123109 & .0833466 & .1622458 & .0136818 \\
\hline 2009-10 & .0511652 & .0035344 & .3390803 & .1027936 & .0149804 \\
\hline 2009-11 & .0454757 & .0220231 & .0779816 & .1142892 & .0156718 \\
\hline 2009-12 & .0281755 & .0247356 & .0494992 & .1015412 & .012777 \\
\hline 2010-01 & .0267507 & .013913 & .1129225 & .0720957 & .0140406 \\
\hline 2010-02 & .0260715 & .0241756 & .3470171 & .0916559 & .0150177 \\
\hline 2010-03 & .0304023 & .0512098 & .1443718 & .0788314 & .0141399 \\
\hline 2010-04 & .0285891 & .0503641 & .1597678 & .0699797 & .0112508 \\
\hline 2010-05 & .0227749 & 0390193 & .1312711 & .0824923 & .0102307 \\
\hline 2010-06 & .0223846 & .0628572 & .3587197 & .0784869 & .0058331 \\
\hline 2010-07 & .0170731 & .0669069 & .1711796 & .1245219 & .0027721 \\
\hline 2010-08 & .0148235 & .0613547 & .28687 & .3885073 & .0017811 \\
\hline 2010-09 & .0166706 & .0441752 & .4271845 & .2802676 & .0012884 \\
\hline 2010-10 & .0126736 & .0088268 & .2321528 & .2198767 & .001413 \\
\hline
\end{tabular}

Note: this table reports monthly average in absolute values of the efficiency scores developed in Emerson et.al (1997) 